Cultural Heritage and Tourism 


\section{ASPECTS OF TOURISM TEXTS}

Series Editors: Professor Chris Cooper (Oxford Brookes University, Oxford, UK), Dr C. Michael Hall (University of Canterbury, Christchurch, New Zealand)

and Dr Dallen J. Timothy (Arizona State University, Phoenix, USA)

This new series of textbooks aims to provide a comprehensive set of titles for higher level undergraduate and postgraduate students. The titles will be focused on identified areas of need and reflect a contemporary approach to tourism curriculum design. The books are specially written to focus on the needs, interests and skills of students and academics. They will have an easy-to-use format with clearly defined learning objectives at the beginning of each chapter, comprehensive summary material, end of chapter review questions and further reading and websites sections. The books will be international in scope with examples and cases drawn from all over the world.

Full details of all the books in this series and of all our other publications can be found on http://www.channelviewpublications.com, or by writing to Channel View Publications, St Nicholas House, 31-34 High Street, Bristol BS1 2AW, UK. 


\section{ASPECTS OF TOURISM TEXTS}

Series Editors: Chris Cooper (Oxford Brookes University, UK),

C. Michael Hall (University of Canterbury, New Zealand)

and Dallen J. Timothy (Arizona State University, USA)

\section{Cultural Heritage and Tourism An Introduction}

Dallen J. Timothy 


\section{Library of Congress Cataloging in Publication Data}

A catalog record for this book is available from the Library of Congress.

Timothy, Dallen J.

Cultural Heritage and Tourism: An Introduction/Dallen J. Timothy.

Aspects of Tourism Texts: 4

Includes bibliographical references and index.

1. Heritage tourism. I. Title. II. Series.

G156.5.H47D35 2011

$338.4^{\prime} 791-d c 222011015350$

\section{British Library Cataloguing in Publication Data}

A catalogue entry for this book is available from the British Library.

ISBN-13: 978-1-84541-177-0 (hbk)

ISBN-13: 978-1-84541-176-3 (pbk)

\section{Channel View Publications}

UK: St Nicholas House, 31-34 High Street, Bristol BS1 2AW, UK.

USA: UTP, 2250 Military Road, Tonawanda, NY 14150, USA.

Canada: UTP, 5201 Dufferin Street, North York, Ontario M3H 5T8, Canada.

Copyright (C) 2011 Dallen J. Timothy.

All rights reserved. No part of this work may be reproduced in any form or by any means without permission in writing from the publisher.

The policy of Multilingual Matters/Channel View Publications is to use papers that are natural, renewable and recyclable products, made from wood grown in sustainable forests. In the manufacturing process of our books, and to further support our policy, preference is given to printers that have FSC and PEFC Chain of Custody certification. The FSC and/or PEFC logos will appear on those books where full certification has been granted to the printer concerned.

Typeset by The Charlesworth Group.

Printed and bound in Great Britain by Charlesworth Press. 